\title{
AKTIVITAS PENGENDALIAN INTERNAL PADA PEMERINTAH KOTA PUSAKO DALAM PEMAHAMAN FUNGSIONALISME STRUKTURAL PARSONS
}

\author{
Yudi* \\ Sri Rahayu \\ Universitas Jambi, Jalan Raya Jambi- Muara Bulian, Km 15, Jambi \\ yudi.telanai@gmail.com
}

\author{
A R T I C L E I N F O \\ Article history \\ Received August 28, 2018 \\ Revised October 5, 2018 \\ Accepted October 30, 2018
}

Key words:

Government, Internal Control, Enviromental Control, Structural Functionalism Theory

\begin{abstract}
A B S T R A C T
The research of this interpretive study is about the activities of internal control in the government of Pusako City in Jambi Province. The researcher used Parsons' structural functionalism theory to understand each role of the internal control factor. The results of this theory analysis are that all sub systems in a system must interact with each other even though the process allows conflict. The results of the study found that internal control had not gone well. The causes are internal control factors such as organizational structure, division of tasks and responsibilities, the role of leaders, commitment to competence, and Human Resource (HR) policies that are not yet integrated
\end{abstract}

\begin{abstract}
A B S T R A K
Penelitian atas studi interpretif ini adalah tentang kegiatan pengendalian internal di Kota Pusako di Provinsi Jambi. Peneliti menggunakan teori struktural fungsionalisme Parsons untuk memahami peran dari faktor kontrol internal. Hasil dari analisis teori ini adalah semua sub sistem dalam suatu sistem harus saling berinteraksi walaupun dalam prosesnya memungkinkan terjadi konflik. Hasil penelitian menemukan bahwa pengendalian internal belum berjalan dengan baik. Penyebabnya adalah faktor kontrol internal seperti struktur organisasi, pembagian tugas dan tanggung jawab, peran pemimpin, komitmen terhadap kompetensi, dan Kebijakan Sumber Daya Manusia (SDM) yang belum terintegrasi.
\end{abstract}

\section{PENDAHULUAN}

Penerapan akuntansi berbasis akrual merupakan kebutuhan reformasi di bidang keuangan negara. Sebagai wujud komitmen terhadap kebutuhan reformasi ini, pemerintah mengeluarkan Keputusan Menteri Keuangan No. 123 Tahun 2012 tentang program reformasi penganggaran dan perbendaharaan negara (RPPN). Salah satu tujuan RPPN adalah mengendalikan anggaran negara, aset, serta kewajiban. Salah satu upaya untuk mencapai tujuan tersebut melalui pengendalian internal pemerintah baik pada pemerintah pusat maupun pemerintah daerah. Kebutuhan pemerintah daerah akan sistem pengendalian intern adalah suatu hal yang wajar, karena dengan adanya praktek pengendalian intern yang baik merefleksikan adanya manajerial yang baik pula. Adanya praktik manajemen yang baik akan meningkatkan kepercayaan masyarakat terhadap pemerintah daerah dalam mengelola sumber daya yang terbatas secara efisien, menjaga agar tidak terjadi kebocoran dan penyimpangan penggunaan aset daerah.

Hasil audit BPK atas laporan keuangan pemerintah daerah (LKPD tahun 2009 sampai dengan tahun 2013 untuk masing-masing tingkat pemerintahan daerah adalah sebagai berikut:

Tabel 1. Perkembangan Opini LKPD Tahun 2009 s.d. Tahun 2013

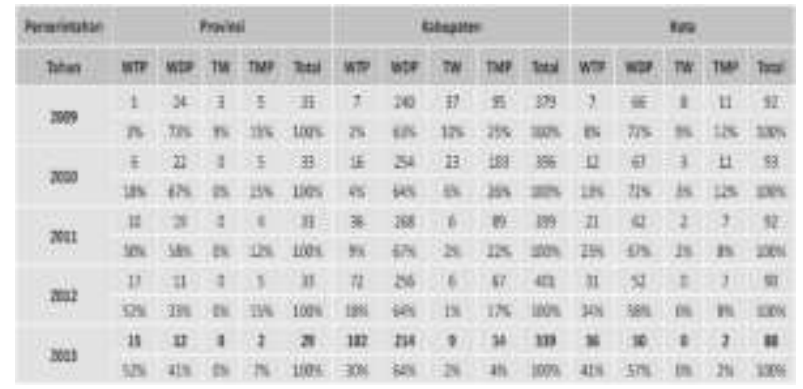

Sumber data: Laporan hasil Audit BPK tahun 2014 
Hasil pemeriksaan atas LKPD menunjukkan peningkatan persentase opini WTP, dan penurunan persentase opini WDP serta TMP. Hal tersebut menggambarkan adanya perbaikan entitas pemerintah daerah dalam menyajikan laporan keuangan yang wajar sesuai dengan prinsip akuntansi yang berlaku. Penyajian laporan keuangan yang wajar merupakan gambaran dan hasil dari pengelolaan keuangan yang lebih baik. Namun demikian, BPK masih menemukan 2\% LKPD yang beropini Tidak Mengeluarkan Pendapat (TMP). Penyebab dikeluarkan opini TMP oleh BPK adalah kelemahan pengelolaan yang material pada akun aset tetap, kas, piutang, persediaan, investasi permanen dan non permanen, aset lainnya, belanja pegawai, belanja barang dan jasa, serta belanja modal (BPK, 2014, p. 25). Menanggapi temuan BPK, Menteri Keuangan, Sri Mulyani mengatakan bahwa opini laporan keuangan disclaimer atau tidak memberi pendapat Pemerintah Pusat tahun 2006, 2005, dan 2004 disebabkan masih adanya kelemahan pengendalian internal di instansi-instansi pemerintah (Merdeka, 2007). Menurut Penulis, pengendalian internal yang lemah merupakan kegagalan pemerintah daerah sebagai sebuah organisasi dalam proses mencapai tujuan tertentu, misalnya dalam hal ini mencapai opini WTP. Pengendalian internal yang lemah membuka ruang meningkatnya perilaku koruptif di lingkungan pemerintah daerah. Penulis merangkum dua kasus korupsi di Provinsi Jambi. Pertama, Kasus dugaan korupsi penggunaan dana rutin anggaran belanja DPRD Sarolangun-Jambi menjadi insentif pimpinan dan para anggota dewan senilai Rp. 816 juta selama tahun anggaran 2003. Uang itu diterima anggota dewan per bulan. Kasus ini telah dilimpahkan ke kejaksaan negeri Sarolangun (Kurniawan, 2006). Kedua, berkas kasus korupsi pada dinas pemuda, pariwisata dan olahraga (Disporada) penyidik kejaksaan negeri Sarolangun-Jambi melimpahkan ke pengadilan negeri Sarolangun Jambi. Hasil audit BPKP Jambi menemukan tindak pidana korupsi merugikan negara senilai Rp. 109 juta pada tahun anggaran 2005. (Independen, 2007).

Pemberlakuan otonomi daerah di Indonesia berikut desentralisasi anggarannya berperan dalam meningkatkan kebutuhan sistem pengendalian internal (Martani dan Zaelani, 2011; Widyaningsih, Triantoro, dan Wiyantoro, 2011; Winidyaningrum dan Rahmawati, 2010). Aktivitas pengendalian merupakan kebijakan dan prosedur yang membantu memastikan bahwa perintah manajemen telah dilaksanakan (Boynton, Johnson, dan Kelly, 2003) Aktivitas pengendalian membantu memastikan bahwa tindakan yang diperlukan berkenaan dengan risiko telah diambil untuk pencapaian tujuan organisasi. Selama ini, penelitian tentang organisasi didominasi unit analisis tingkat makro (Jones, 2008; Shapiro dan Matson, 2008). Beberapa peneliti seperti Covaleski and Dirsmith (1988), Ter Bogt (2008), Norhayati and Siti-Nabiha (2009), Djamhuri (2009), dan Harun dan Kamase (2012) juga meneliti bidang akuntansi dengan di tingkat makro dengan menggunakan perspektif new institutionalism (lihat juga Gill, 2014). Padahal, Gill (2014) menjelaskan bahwa penelitian tentang organisasi juga berkembang pada unit analisis tingkat mikro atau individu. Suddaby (2010) pun menemukan studi terhadap institusi yang dilakukan oleh individu-individu, sangat mengejutkan karena peran dari individu-individu ini justru tidak terlihat dalam studi ini. Padahal, logika institusional memiliki komponen persepsi yang secara kognisi beroperasi pada tingkat individu. Oleh karena itu, terdapat peluang untuk meneliti bagaimana organisasi atau institusi dianalisis pada tingkat individu.

Opini laporan keuangan pemerintah Kota Pusako pada tahun 2014 masih berupa pernyataan tidak memberi pendapat tahun 2014. Catatan rekomendasi dari BPK terhadap opini tersebut terutama berkaitan dengan pencatatan dan penilaian aset daerah, baik berupa aset tetap maupun aset tetap lainnya. Berdasarkan rekomendasi BPK tersebut, Penulis meyakini bahwa implementasi pengendalian internal yang diterapkan pada Satuan Kerja Pengelola Keuangan Daerah (SKPKD) Kota Pusako (nama samaran sebuah daerah di Provinsi Jambi) masih lemah. Kondisi ini sesuai dengan tanggapan dari Menteri Keuangan yang menyatakan bahwa opini laporan keuangan tidak memberi pendapat disebabkan kelemahan pengendalian internal di pemerintah daerah. Untuk mengetahui bagaimana kondisi tersebut terjadi, Penulis mengeksplorasi pemahaman pegawai pemerintah daerah terhadap implementasi pengendalian internal yang diterapkan oleh SKPKD dengan menggunakan teori struktural fungsionalisme. Teori ini berguna untuk memahami realitas sosial yang terbentuk saat melaksanakan pengendalian intern.

\section{KAJIAN LITERATUR DAN PENGEMBANGAN HIPOTESIS}


Pengendalian Akuntansi sebagai bagian dari Sistem Pengendalian Intern

Menurut The American Institute of Certified Public Accountants (AICPA) Pengendalian intern adalah:

"The plan of organization, and all of the coordinate methods and measures adopted within a business, to safeguard its assets, check the accuracy and reliability of its accounting data, promote operational efficiency, and encourage adherence to prescribed managerial policies (AU Section 320.08)"

Definisi sistem pengendalian internal tersebut menekankan tujuan yang hendak dicapai dan bukan pada unsur-unsur yang membentuk sistem tersebut. Dengan demikian, pengertian pengendalian internal tersebut berlaku baik untuk organisasi yang mengolah informasinya secara manual, dengan mesin pembukuan, maupun dengan komputer. Tujuan sistem pengendalian internal menurut definisi tersebut adalah untuk: (1) menjaga kekayaan organisasi, (2) mengecek ketelitian dan keandalan data akuntansi, (3) mendorong efisiensi, dan (4) mendorong dipatuhinya kebijakan manajemen.

Pengendalian internal dapat dibagi menjadi dua yaitu: (1) pengendalian administrasi (administrative control), merupakan pengendalian yang menjamin efisiensi operasional dan ketaatan kebijakan manajemen. (2) pengendalian akuntansi (accounting control), merupakan pengendalian yang bertujuan untuk membantu menjaga aktiva dan menjamin akurasi dan daya andal catatan keuangan perusahaan (Krismiaji, 2015). Triyuwono dan Roekhudin (2000) menyatakan bahwa fungsi pengendalian akuntansi adalah untuk menjaga aktiva dan mengecek keakuratan dan reliabilitas data akuntansi sehingga mencegah terjadinya inefisiensi. Oleh karena itu fungsi ini dinamakan preventive atau accounting control.

Sejalan dengan tujuan pengendalian akuntansi, Permendagri No. 13 Tahun 2006 yang mengatur pengeluaran keuangan daerah melalui penatausahaan pengeluaran yang diakomodir dalam pasal 196 hingga pasal 231. Peraturan penatausahaan pengeluaran ini menjadi dasar untuk menganalisa praktik yang menjadi temuan penelitian.

Teori Fungsionalisme Struktural untuk Membangun Pemahaman terhadap Aktivitas Pengendalian

Fungsionalisme struktural, terutama dalam karya Talcott Parsons, Robert Merton, serta pengikut mereka (seperti Bronislaw Malinowski, Radclif-Brown, dan Alvin Gouldner (Poloma, 2004) memusatkan perhatian pada "struktur sosial" dan "institusi sosial" berskala luas, antar hubungannya, dan pengaruhnya terhadap aktor. Dalam fungsionalisme struktural, istilah struktural dan fungsional tidak selalu perlu dihubungkan, meski keduanya biasa dihubungkan. Struktur suatu masyarakat dapat dipelajari tanpa memperhatikan fungsinya (atau akibatnya) terhadap struktur lain. Begitu pula ketika meneliti suatu fungsi berbagai proses sosial yang mungkin tidak mempunyai struktur (Ritzer dan Goodman, 2012). Ini memberikan perspektif bahwa kenyataan sosial sangat luas, tidak terbatas pada tingkat struktur sosial saja. Struktur sosial hanya salah satu dari sistem-sistem yang terbentuk dari tindakantindakan sosial individu, seperti halnya sistem kepribadian, dan sistem budaya.

Parsons melihat sistem sosial sebagai satu dari tiga cara di mana tindakan sosial bisa diorganisir, dua sistem lainnya adalah sistem kultural yang mengandung nilai dan simbol-simbol serta sistem kepribadian para pelaku individual (Poloma, 2004). Sistem sosial terdiri dari sejumlah aktor individu yang saling berinteraksi dalam situasi yang paling tidak terdiri dari aspek lingkungan atau fisik, aktor-aktor yang mempunyai motivasi dalam arti mempunyai kecenderungan untuk mengoptimalkan "kepuasan", yang hubungannya dengan situasi mereka didefinisikan dan dimediasi dalam batasan sistem simbol bersama yang terstruktur secara kultural (Ritzer dan Goodman, 2012; Robert, 2006). Individu yang merencanakan tindakannya untuk mencapai tujuan pada dasarnya memiliki kesadaran akan hadirnya individu-individu lainnya yang juga memiliki seperangkat ide, kepercayaan, nilai dan pola normatif yang memberikan kesempatan dan memberikan batasbatas pada tindakan individu untuk mengoptimalkan "kepuasan" (tujuan individu).

Dalam sistem sosial, Parsons menekankan status-peran sebagai unit fundamental dalam studi tentang sistem sosial. Status mengacu pada posisi struktural dari sistem sosial, dan peran adalah apa yang dilakukan aktor dalam posisinya itu. Parsons menjelaskan sejumlah persyaratan fungsional dalam sistem sosial. Pertama, sistem sosial harus terstruktur (ditata) sedemikian rupa sehingga bisa beroperasi dalam hubungan yang harmonis dengan sistem lainnya. Kedua, untuk menjaga kelangsungan hidupnya, sistem sosial harus mendapatkan dukungan yang diperlukan dari sistem yang lain. Ketiga, sistem sosial harus 
mampu memenuhi kebutuhan para aktornya dalam proporsi yang signifikan. Keempat, sistem harus mampu melahirkan partisipasi yang memadai dari para anggotanya. Kelima, sistem sosial harus mampu mengendalikan perilaku yang berpotensi mengganggu. Keenam, bila konflik akan menimbulkan kekacauan, itu harus dikendalikan. Ketujuh, untuk kelangsungan hidupnya, sistem sosial memerlukan bahasa (Ritzer dan Goodman, 2012). Disini jelas bahwa Parsons memperhatikan pemeliharaan keteraturan di dalam sistem sosial.

Dengan menghubungkan individu yang terdapat dalam sistem sosial maka sistem sosial dapat dianalisa melalui konsep status dan peranan. Status adalah kedudukan dalam sistem sosial, seperti guru, dan peranan adalah perilaku yang diharapkan atau perilaku normatif yang melekat pada status guru itu. Dengan kata lain dalam sistem sosial individu menduduki suatu tempat (status), dan bertindak (peranan) sesuai dengan norma atau aturan-aturan yang dibuat oleh sistem. Peranan yang dilakukan individu memiliki sifat timbal balik, dalam arti status sebagai "guru" mengandung peranan normatif (misalnya menjadi seorang pengajar yang baik) mencakup ketergantungan dengan peranan "murid".

Dalam menganalisis sistem sosial, Parsons menganggap integrasi dan pola nilai dan kecenderungan kebutuhan sebagai "dalil dinamis fundamental sosiologi" (Ritzer dan Goodman, 2012). Dalam proses sosial yang berhasil, norma dan nilai itu diinternalisasikan (internalized); artinya, norma dan nilai itu menjadi bagian dari "kesadaran aktor". Akibatnya, dalam mengejar kepentingan mereka itu sendiri, aktor sebenarnya mengabdi pada kepentingan sistem sebagai satu kesatuan.

Meski ada penyesuaian yang diakibatkan oleh sosialisasi terus menerus, namun tetap ada sejumlah besar perbedaan individual dalam sistem (Ritzer dan Goodman, 2012). Masalahnya adalah: mengapa perbedaan individual ini biasanya tidak menjadi problem besar bagi sistem sosial, padahal sistem sosial memerlukan keteraturan? Menurut Ritzer dan Goodman (2012) hal ini disebabkan; pertama, sejumlah mekanisme pengendalian sosial dapat digunakan untuk mendorong ke arah penyesuaian. Parsons menganggap pengendalian sosial sebagai pertahanan lapis kedua. Sebuah sistem sosial berjalan dengan baik bila pengendalian sosial hanya digunakan dengan hemat.

Kedua, sistem sosial harus mampu menghormati perbedaan, bahkan penyimpangan tertentu. Sistem sosial yang fleksibel lebih kuat ketimbang yang kaku, yang tidak dapat menerima penyimpangan. Ketiga, sistem sosial harus menyediakan berbagai jenis peluang untuk berperan yang memungkinkan bermacam-macam kepribadian yang berbeda untuk mengungkapkan mereka sendiri tanpa mengancam integritas sistem.

Sebagai seorang fungsionalis struktural, Parsons membedakan empat fungsi penting untuk semua sistem "tindakan", terkenal dengan skema AGIL (Adaptation, Goal attainment, Integration, dan Latency) (Perdue, 1986; Ritzer dan Goodman, 2012; Robert, 2006; Turner, 1998), yaitu Adaptation (Adaptasi) merupakan sebuah sistem harus menanggulangi situasi eksternal yang gawat. Sistem harus menyesuaikan diri dengan lingkungan dan menyesuaikan lingkungan itu dengan kebutuhannya; Goal attainment (Pencapaian tujuan) merupakan sebuah sistem harus mendefinisikan dan mencapai tujuannya; Integration (Integrasi) merupakan sebuah sistem harus mengatur antarhubungan bagianbagian yang menjadi komponennya. Sistem juga harus mengelola antarhubungan ketiga fungsi lainnya (A, G, L); Latency (Latensi pemeliharaan pola) dapat dikatakan sebagai sebuah sistem yang harus memiliki, memelihara, dan memperbaiki, baik motivasi individual maupun pola-pola kultural yang menciptakan dan menopang motivasi. Suatu sistem harus memiliki empat fungsi tersebut untuk terus bertahan.

\section{METODE PENELITIAN}

Mempertimbangkan realita implementasi pengendalian internal di pemerintah daerah yang menjadi bidang kajian penelitian sudah tentu menyangkut dimensi kemanusiaan, maka penelitian ini dilakukan berdasarkan dimensi subyektif yang memerlukan obyek yang berkaitan dengan manusia yang memiliki tindakan bermakna (Fatchan, 2013). Oleh karena itu metode yang sangat mendasar untuk mendalami dimensi kemanusiaan adalah metode pemahaman (verstehen, sebuah konsep yang pertama kali dikemukakan oleh Weber) untuk memahami makna tindakan manusia (Kuswarno, 2009). Menurut Kuswarno (2009), inti dari konsep pemahaman Weber ini mengarah pada suatu tindakan bermotif demi tujuan yang hendak dicapai. Konsep ini membuka pemahaman interpretatif. Penulis menggunakan paradigma interpretif untuk melaksanakan mengkaji dimensi kemanusiaan tersebut.

Pendekatan penelitian yang digunakan 
adalah deskripsi kualitatif. Bungin (2011) menjelaskan bahwa deskriptif kualitatif menganut paham fenomenologi yang mengkaji penampakan atau fenomena di mana fenomena dan kesadaran tidak terisolasi satu dengan yang lain melainkan selalu berhubungan secara dialektis hanya saja penelitian deskriptif kualitatif menempatkan teori pada data yang diperolehnya. Penulis menggunakan teori Fungsionalisme Strukturalisme Parsons untuk mengeksplorasi faktor-faktor yang tercakup dalam lingkungan pengendalian antara lain: Komitmen terhadap kompetensi, filosofi manajemen dan gaya kepemimpinan, struktur organisasi, cara pembagian otoritas dan tanggung jawab, dan kebijakan sumber daya manusia dan prosedur (Bodnar dan Hopwood, 2007). Sciortin (2012) menjelaskan bahwa dalam sistem sosial, Parsons menekankan status-peran sebagai unit fundamental dalam studi tentang sistem sosial. Status mengacu pada posisi struktural dari sistem sosial, dan peran adalah apa yang dilakukan aktor dalam posisinya itu. Bungin (2011) menjelaskan tujuan deskriptif kualitatif adalah menggambarkan, meringkaskan berbagai kondisi, berbagai situasi, atau berbagai fenomena realitas sosial yang ada di masyarakat dan berupaya menarik realitas itu ke permukaan sebagai suatu ciri, karakter, sifat, model, tanda, atau gambaran tentang kondisi, situasi, ataupun fenomena tertentu.

Dari ciri yang dijelaskan oleh Bungin sebelumnya, penelitian ini memusatkan pada suatu unit tertentu sehingga analisis data dapat dilakukan secara mendalam. Data dieksplorasi dan dianalisis dengan cara mengkomparasikan temuan atau pemahaman atas kenyataan sosial organisasi yang bersifat empiris dengan konsep atau teori yang terkait. Selanjutnya, Penulis menganalisis realitas sosial pengendalian internal dengan menggunakan teori struktural fungsionalisme Parsons.

Penelitian ini dilakukan pada salah satu SKPKD di Provinsi Jambi. Penulis memilih SKPKD bukan SKPD dangan alasan SKPKD memiliki dua fungsi akuntansi (Mendagri, 2007). Fungsi akuntansi pertama adalah mencatat dan melaporkan transaksi SKPKD selaku satuan kerja. Fungsi akuntansi kedua adalah mencatat dan melaporkan transaksi pemerintah daerah yang dilaksanakan oleh Bendahara Umum Daerah (BUD)/Pejabat Pengelola Keuangan Daerah (PPKD) serta melakukan penggabungan laporan keuangan seluruh satuan kerja (termasuk SKPKD sebagai satuan kerja) dan BUD/PPKD menjadi laporan keuangan pemerintah daerah. Sementara
SKPD hanya memiliki fungsi pertama saja. Berdasarkan pertimbangan alasan ini, SKPKD memiliki tanggung jawab organisasi yang lebih luas dibandingkan ddengan SKPD. Informan pada penelitian ini adalah pegawai SKPKD Kota Pusako. Informan yang dipilih dalam penelitian ini adalah para aparatur yang terlibat langsung dan mempunyai pengalaman dalam pengelolaan keuangan. Daftar informan dapat dilihat pada tabel 1. Identitas informan yang digunakan bukan nama informan yang sebenarnya atas permintaan dari informan.

Tabel 1. Daftar Nama Informan dan Jabatan

\begin{tabular}{|c|l|l|}
\hline No & Inisial Nama & \multicolumn{1}{|c|}{ Jabatan } \\
\hline 1 & Pak Ruta & $\begin{array}{l}\text { Kasubbag Anggaran } \\
\text { /Kuasa BUD }\end{array}$ \\
\hline 2 & Ibu Sarah & Kasubbag Pembukuan \\
\hline 3 & Pak Mandra & Staf Verifikasi \\
\hline 4 & Pak Solihin & Staf Anggaran \\
\hline 5 & Ibu Eli & Staf Anggaran \\
\hline
\end{tabular}

Berdasarkan kriteria Moustakas (1994), Peneliti memilih informan yang memiliki pengalaman terhadap pengelolaan keuangan. Informan yang memiliki pengalaman diperolehi informasi lisan dan tertulis/dokumen. Informan yang diperoleh secara lisan direkrut dari informaninforman yang memberikan kontak dan rekomendasi untuk diwawancara (metode snowball). Metode ini adalah suatu bentuk purposive sampling yang biasanya terjadi setelah penelitian dimulai dan ketika peneliti meminta partisipan untuk merekomendasikan individu lain untuk diambil sebagai sampel. Peneliti mengenal dengan sangat dekat staf ahli dari PPAB Universitas Brawijaya yang menjadi konsultan pengelolaan keuangan daerah Kota Pusako. Informan lainnya diperoleh berdasarkan kriteria Moustakas.

Pengumpulan data dilakukan melalui pengamatan berpartisipasi, wawancara mendalam dengan para informan dan dokumentasi. Pengamatan berpartisipasi dilakukan dengan cara keterlibatan peneliti di dalam proses pengelolaan keuangan pada bulan Maret dan Mei tahun 2006. Wawancara dilakukan secara tidak terstruktur dan informal dalam berbagai situasi. Dokumentasi digunakan untuk mengungkap realitas sosial yang terjadi yang terdapat dalam suatu dokumen.

Proses analisis data yang digunakan pada penelitian ini mengacu kepada analisis data model interaktif Miles dan Huberman (Miles, Huberman, dan Saldana, 2014). Dalam model ini terdapat tiga 
komponen analisis, yaitu reduksi, penyajian data dan penarikan kesimpulan. Selanjutnya analisis dilakukan dengan memadukan (secara interaktif) ketiga komponen tersebut. Inti analisis data menurut Lan Dey (1993) dalam (Moleong, 200) terletak pada tiga proses yaitu mendeskripsikan fenomena, mengklasifikasikannya dan melihat bagaimana konsep-konsep yang muncul itu satu dengan yang lainnya saling berkaitan.

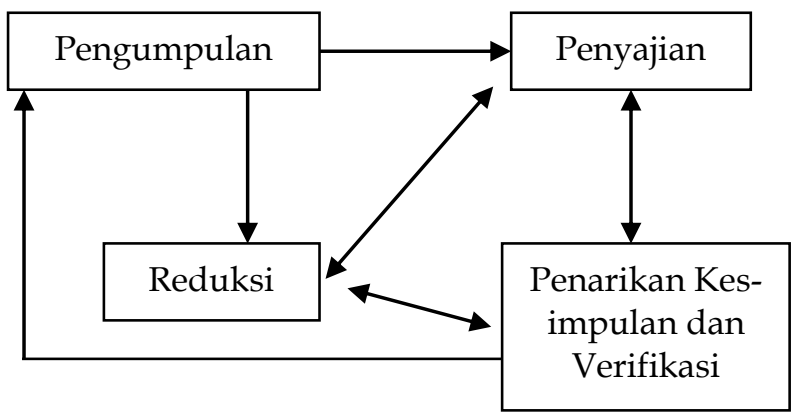

\section{Gambar 1. Analisis Data Model Interaktif Miles dan Huberman}

Reduksi data dilakukan dengan diawali mengelompokkan data yang relevan dengan pelaksanaan aktivitas pengendalian akuntansi sektor publik, sistem akuntansi dan kebijakan akuntansi sektor publik di pemerintah daerah. Setelah pengelompokan data dilakukan, kemudian disarikan substansi (isi) utama dari data yang diperoleh. Proses analisis data merupakan proses terus menerus dan dimulai sejak turun ke situs penelitian. Sebelum melaksanakan interview dan pengamatan langsung, berbagai informasi dan dokumen yang berkaitan dengan bidang kajian penelitian terus ditelaah dan dipelajari. Penekanan terhadap bukti dan data lapangan dilakukan untuk meyakinkan keabsahan data melalui metode triangulasi. Proses reduksi data dilakukan secara terus menerus hingga ditemukan tema-tema kunci yang akan diplot dalam bentuk narasi.

Selanjutnya, Peneliti melakukan analisis aktivitas pengendalian akuntansi berdasarkan perspektif Functionalism Structural Parsons. Struktural fungsionalisme Parsons mensyaratkan bahwa suatu sistem dan tindakan manusia harus menyesuaikan diri dengan lingkungan. Dalam konteks inilah kerangka Adaptation, Goal Attainment, Integration, Latent Maintenance (A-G-I-L) digunakan untuk melihat aktivitas pengendalian akuntansi, utamanya faktor-faktor lingkungan pengendalian intern yang merupakan pondasi untuk melaksanakan aktivitas pengendalian akuntansi sektor publik di SKPKD kota Pusako.

\section{HASIL DAN PEMBAHASAN}

Bodnar dan Hopwood (2007) mengingatkan bahwa yang menjadi pondasi dari pengendalian internal adalah lingkungan pengendalian karena menyediakan disiplin dan struktur komponen proses pengendalian internal. Lebih lanjut Bodnar dan Hopwood (2007) mengemukakan bahwa lingkungan pengendalian merupakan dampak kumulatif atas faktor-faktor untuk membangun, mendukung dan meningkatkan efektivitas kebijakan dan prosedur tertentu. Dengan kata lain lingkungan pengendalian menentukan iklim organisasi dan mempengaruhi kesadaran pegawai terhadap pengendalian. Sistem pengendalian internal menurut Boynton dkk. (2003) terdiri dari lima elemen, yaitu: lingkungan pengendalian, penaksiran resiko, aktivitas pengendalian, informasi dan komunikasi, serta pengawasan.

Pengendalian internal dapat dibagi menjadi dua yaitu: Pertama, pengendalian administrasi yang merupakan pengendalian yang menjamin efisiensi operasional dan ketaatan kebijakan manajemen. Kedua, pengendalian akuntansi yang bertujuan untuk membantu menjaga aktiva dan menjamin akurasi dan daya andal catatan keuangan (Krismiaji, 2015). Seperti Krismiaji, Triyuwono and Roekhuddin (2000) menjelaskan bahwa fungsi pengendalian akuntansi adalah untuk menjaga aktiva dan mengecek keakuratan dan reliabilitas data akuntansi sehingga mencegah terjadinya inefisiensi. Oleh karena itu fungsi ini dinamakan preventive atau accounting control. Menurut Bastian (2010), Pengendalian akuntansi merupakan bagian dari sistem pengendalian internal, meliputi struktur organisasi, metode, dan ukuran-ukuran yang dikoordinasikan terutama untuk menjaga kekayaan organisasi serta mengecek ketelitian dan keandalan data akuntansi. Selanjutnya, Bastian (2010) menjelaskan bahwa pengendalian akuntansi merupakan bagian dari sistem pengendalian internal yang meliputi struktur organisasi, metode, dan ukuran-ukuran yang dikoordinasikan terutama untuk menjaga kekayaan organisasi serta mengecek ketelitian dan keandalan data akuntansi.

Manusia sebagai mahluk sosial tidak bisa lepas dari keberadaan organisasi dalam melakukan aktivitas sehari-hari karena keterbatasan kemampuan yang dimilikinya. Oleh karenanya manusiapun melibatkan diri ke dalam berbagai organisasi. Organisasi pada dasarnya merupakan suatu bentuk kerja sama antar individu dan merupakan pula proses penggabungan aktivitas untuk mencapai tujuan yang telah ditentukan 
bersama (Gibson, Ivancevich dan James, 1997). Pada hakekatnya sebuah organisasi tidak berdiri sendiri yang juga merupakan bagian dari sebuah sistem yang lebih besar dengan memuat unsur lain seperti keluarga, pendidikan, pemerintahan dan organisasi lain. Ini menunjukkan bahwa proses aktivitas organisasi tidak terlepas dari pengaruh lingkungan di mana organisasi berada. Manusia yang berada dalam organisasi tersebut harus selalu mempunyai sikap responsif terhadap lingkungan, termasuk tuntutan untuk selalu meningkatkan kinerja atau produktivitasnya dengan pengertian bekerja lebih cepat, tepat dan tanggap pada kebutuhan organisasi tersebut.

Organisasi sebagai sistem sosial, dalam pandangan Parsons, menggunakan sejumlah persyaratan fungsional (Ritzer dan Goodman, 2012) . Pertama, sistem sosial harus terstruktur (ditata) sedemikian rupa sehingga bisa beroperasi dalam hubungan yang harmonis dengan sistem lainnya. Kedua, untuk menjaga kelangsungan hidupnya, sistem sosial harus mendapatkan dukungan yang diperlukan dari sistem yang lain. Ketiga, sistem sosial harus mampu memenuhi kebutuhan para aktornya dalam proporsi yang signifikan. Keempat, sistem harus mampu melahirkan partisipasi yang memadai dari para anggotanya. Kelima, sistem sosial harus mampu mengendalikan perilaku yang berpotensi mengganggu. Keenam, bila konflik akan menimbulkan kekacauan, itu harus dikendalikan. Ketujuh, untuk kelangsungan hidupnya, sistem sosial memerlukan bahasa .

Parsons membedakan empat fungsi penting untuk semua sistem "tindakan", terkenal dengan skema AGIL (Adaptation, Goal attainment, Integration, dan Latency) (Ritzer dan Goodman, 2012; Sciortin, 2012). Empat fungsi tersebut dapat menjaga keberlanjutan sebuah sistem. Fungsi adaption atau adaptasi merupakan sebuah sistem yang harus menanggulangi situasi eksternal yang gawat. Sistem ini harus menyesuaikan diri dengan lingkungan dan menyesuaikan lingkungan tersebut sesuai dengan kebutuhannya. Fungsi goal attainment atau pencapaian tujuan mengisyaratkan bahwa sebuah sistem harus mendefinisikan dan mencapai tujuannya. Fungsi Integration atau integrasi menunjukkan bahwa sebuah sistem harus mengatur antarhubungan setiap bagian yang menjadi komponennya. Sistem juga harus mengelola antar hubungan ketiga fungsi lainnya (adaptasi, pencapaian tujuan, dan latensi). Latency atau latensi mensyaratkan bahwa sebuah sistem harus melengkapi, memelihara, dan memperbaiki, baik motivasi individual maupun pola-pola kultural yang menciptakan dan menopang motivasi.

Organisasi, struktur organisasi serta cara pembagian otoritas dan tanggung jawab. Dalam sejarah setiap organisasi, tak peduli organisasi apapun, pada suatu saat pasti akan mengalami satu situasi "tidak selaras" (Albrecht, 1985). Keadaan tidak selaras ini tidak selalu diakibatkan oleh manajemen yang lemah atau tidak efektif, walaupun tentu saja hal yang serupa itu bisa terjadi. Keadaan tersebut lebih sering terjadi oleh kelembaman (KBBI mengartikan kelembaman sebagai sifat materi yang menentang atau menghambat perubahan) yang selalu ada dalam hampir setiap organisasi. Kelembaman ini dapat berupa kecenderungan orang-orang bekerja dalam sebuah organisasi untuk mempertahankan gaya kerja "status quo". Namun, Orang-orang dalam organisasi juga menyempurnakan, memelihara, serta akhirnya mempertahankannya dari semua kekuatan dari luar yang menuntut mereka untuk berubah.

Konsekuensi terhadap perubahan peraturan juga terlihat dalam organisasi SKPKD Kota Pusako yang tadinya masih disebut Bagian Keuangan. Perubahan jelas tampak pada komposisi organisasi. Sebelum Perubahan peraturan dari Kepmendagri no. 29 tahun 2002 menjadi Permendagri no. 13 tahun 2006 SKPKD Kota Pusako terdiri dari lima Bagian, yakni: Bagian Anggaran, Bagian Belanja dan Gaji, Bagian Perbendaharaan, Bagian Pembukuan dan Bagian Verifikasi. Setelah berlakunya Permendagri No. 13 Tahun 2006 peran bagian verifikasi akan diserahkan ke masingmasing pengguna anggaran (SKPD). Hal ini akan berakibat pada pengurangan Bagian Verifikasi di organisasi SKPKD. Salah seorang staf bagian verifikasi, Pak Mandra menunjukkan keresahannya dalam pernyataan berikut:

"Dengan struktur yang baru bagian verifikasi masuk ke bagian mana apakah menjadi bagian SKPD atau SKPKD? Hal ini berkaitan dengan tugas yang selama ini dilaksanakan oleh bagian verifikasi untuk memverifikasi SPJ yang akan dipertanggungjawabkan oleh pengguna anggaran. Karena setelah perubahan peraturan dari Kepmen lama ke Permen yang baru sampai sekarang kami tidak mempunyai landasan hukum yang jelas untuk kami melaksanakan tugas. Kalau memang bagian verifikasi ini sudah tidak dipakai lagi lebih baik dibubarkan saja dan 
kami di sebar ke setiap SKPD-SKPD yang membutuhkan untuk memverifikasi SPJ yang akan dipertanggungjawabkan."

Keresahan Pak Mandra disebabkan karena tugas yang biasanya dilaksanakan berdasarkan prosedur dan juknis (petunjuk teknis), SK penunjukan tugas pegawai, serta Penetapan RKA/DPA belum jelas. Tugas yang diberikan kadang hanya bersifat lisan dari pimpinan SKPKD. Kondisi tidak nyaman Pak Mandra dikemukakan dalam penyataan berikut:

"...Iya, saya dipanggil oleh kabag. Katanya saya diperbantukan diperbendaharaan untuk memeriksa SPJ SPP-UP. Saya menolak, karena walaupun SPP-UP nanti telah saya periksa, saya tidak mempunyai kewenangan untuk menolak atau memberi persetujuan SPP yang saya periksa karena tidak secara tegas menyatakan itu. Jadi tidak ada gunanya SPJ tadi diperiksa, lagi pula senjata untuk memeriksa tidak pernah diberikan ke bagian verifikasi, bagaimana kami mau kerja...Kami tidak bisa memepertanggungjawabkan apa yang telah kami lakukan karena dasar kami bekerja berupa SK dan prosedur ataupun petunjuk mengenai apa yang harus dan tidak boleh kami lakukan belum ada..."

Ketidaknyamanan pegawai ini wajar terjadi, karena aparatur pemerintah dalam birokrasi publik di Indonesia bekerja atas dasar wewenang yang telah ditentukan. Aparatur pemerintah dalam birokrasi publik di Indonesia bekerja atas dasar wewenang yang sudah ditentukan (Sutiyono, Sulistiyani, dan Sartono, 2004). Menurut Sutiyono dkk. (2004) ada tiga elemen pokok yang mendasari pengaturan wewenang tersebut: Pertama, kegiatankegiatan yang bersifat rutin tiap-tiap satuan organisasi ditetapkan sebagai tugas-tugas resmi. Tugas-tugas ini relatif stabil artinya tidak mengalami perubahan-perubahan yang berarti. Kedua, wewenang untuk melaksanakan itu sepenuhnya terikat pada aturan yang berlaku. Ketiga, ada keteraturan baik dalam mekanisme maupun prosedur, cara-cara yang sudah baku untuk menjamin kelangsungan pelaksanaan tugastugas oleh (dan hanya oleh) pegawai-pegawai yang memenuhi kualifikasi menurut ketentuanketentuan yang berlaku. Uraian pekerjaan diadakan secara formal agar berbagai unsur di organisasi memahami posisi mereka masingmasing dan jelas siapa mempunyai kewenangan dan tanggung jawab atas apa.

Berdasarkan pengamatan Penulis, hingga memasuki triwulan kedua tahun 2006 SKPKD belum memiliki struktur organisasi yang lengkap sesuai dengan Permendagri No. 13 tahun 2006 (Pelaksanaan Permendagri No. 13 tahun 2006 di SKPKD kota Pusako efektif dimulai pada bulan Januari 2007). Meskipun demikian, organisasi SKPKD Kota Pusako tetap berjalan dengan struktur formal dan uraian pekerjaan seadanya. Perubahan struktur organisasi SKPKD kota Pusako sesuai dengan Permendagri No. 13 Tahun 2006 diantaranya mengangkat kepala SKPKD selaku PPKD yang dalam fungsinya sebagai Bendahara Umum Daerah, dan PPKD selaku BUD menunjuk pejabat di lingkungan satuan kerja pengelolaan keuangan daerah selaku kuasa BUD. Di lapangan didapat temuan bahwa Surat Keputusan (SK) penunjukkan yang dikeluarkan melalui Surat Keputusan Kepala Daerah tidak secara jelas menunjukkan staf-staf yang akan membantu BUD dan Kuasa BUD dalam melaksanakan tugas sehariharinya. Hal ini menimbulkan masalah baru terhadap staf yang ada di SKPKD. Kondisi ini menimbulkan ketidakpastian pegawai dalam bekerja. Ketidakpastian yang dirasakan oleh Pak Ruta, selaku kuasa BUD kota Pusako dijelaskan dalam pernyataan berikut:

"Pegangan hukum yang jelas hanya Permendagri 13, itupun tidak begitu jelas maksudnya seperti apa, sehingga kami yang bertugas bingung untuk melakukan apa. Untuk melaksanakan tugas saya selaku kuasa BUD hanya berdasarkan SK pak Walikota, yang hanya menunjuk Pak Okta sebagai BUD dan saya sebagai kuasa BUD tanpa staf lain sebagai perpanjangan tangan untuk melaksanakan tugas sehari-hari. BUD apa? BUD tidak lengkap. Cuma orang dua. Ini membuat kami agak bingung untuk menyerahkan tugas kepada siapa. Tapi mau tidak mau kami harus menjalankannya karena banyak pihak sangat bergantung pada hasil kerja kita. Organisasi yang ada tidak cocok dengan peraturan yang berlaku, bagaimana dengan pembagian tugasnya? sedangkan aturan ini tidak secara tegas mengatur dan bukan wewenang aturan ini untuk mengatur kelembagaan, aturan ini hanya memberi isyarat untuk membuat aturan lebih lanjut yang akan menjadi dasar hukumnya. Akibatnya pekerjaan yang kami lakukan boleh dikatakan belum ada pijakan."

Pernyataan Pak Ruta sedikit memberikan gambaran ketika sebuah organisasi tidak memiliki struktur organisasi yang baik berpotensi 
menimbulkan "kebingungan" seperti yang dialami oleh Pak Ruta sehingga ia tidak memiliki gambaran yang jelas mengenai wewenang dan tanggung jawab nya dalam organisasi pemerintahan yang berbentuk birokrasi. Sebagai organisasi modern yang konsep dasarnya dikembangkan oleh Max Weber, birokrasi adalah bentuk organisasi kekuasaan yang sepenuhnya diserahkan kepada para pejabat resmi atau aparat pemerintah yang memiliki syarat technical skills (berkemampuan secara teknis melaksanakan tugas yang dipercayakan kepadanya) bagi bekerjanya sistem administrasi pemerintahan (Sutiyono dan Sulistiyani, 2004). Birokrasi bekerja atas dasar prinsip hierarki jabatan, yang diperlihatkan garis komando yang sangat kaku dari atasan kepada bawahan. Atasan membawahkan dan mengawasi bawahan, berdasarkan pembagian tanggung jawab yang sepenuhnya menjadi tanggung jawab bawahan. Kelebihan model birokrasi semacam ini adalah kejelasan tugas, wewenang, tanggungjawab, termasuk kejelasan kepada siapa segala tugas tersebut harus dipertanggungjawabkan.

Struktur organisasi merupakan gambaran atas bangunan berlapis dalam sebuah organisasi yang menentukan hirarki wewenang dan tanggungjawab bagi individu-individu dalam organisasi (Ludigdo, 2007) . Bagi organisasi modern, struktur organisasi mempunyai peran yang sangat penting dalam menentukan putaran roda organisasi. Secara substansial bagan yang menggambarkan struktur organisasi menunjukkan hirarki dalam organisasi yang membedakan peran, wewenang, tanggungjawab, serta jenis dan besaran reward individu yang berposisi pada masingmasing tingkatan hirarkis atau fungsi.

Kondisi yang dimaksudkan oleh Sutiono dan Sulistiyani serta Ludigdo di atas merupakan kondisi ideal dan normatif yang harus ada untuk organisasi formal. Dalam praktiknya organisasi formal yang dikelola oleh SKPKD kota Pusako tidak selalu menunjukkan kondisi seperti di atas. Struktur organisasi yang ada berdasarkan keterangan pak Ruta selaku kuasa BUD kota Pusako sedikit menjelaskan bahwa struktur organisasi SKPKD kota Pusako belum dapat menjadi pedoman bagi semua unsur yang terlibat di SKPKD. Sampai dengan bulan Juni 2007 SKPKD kota Pusako belum mempunyai struktur organisasi yang lengkap dan uraian pekerjaan yang definitif yang diformalkan berdasar surat resmi dari Walikota kota Pusako, hanya surat keputusan yang membentuk BUD dan kuasa BUD SKPKD kota
Pusako. Struktur organisasi yang ada masih merupakan struktur organisasi yang mengacu pada peraturan lama. Diakui pula oleh pak Hasan, selaku Kasubag Anggaran, bahwa struktur organisasi dan uraian pekerjaan yang ada masih mengacu pada peraturan lama, sehingga banyak pekerjaan yang seharusnya mengacu pada peraturan baru dijalankan secara informal dan berdasarkan kebijakan pimpinan, bahkan seringkali pimpinan menyerahkan kebijakan yang membutuhkan pertimbangan khusus berdasarkan saran dari pegawai yang dianggap menguasai pekerjaan.

Ketidakpastian pegawai dalam bekerja mengakibatkan ketidakjelasan uraian pekerjaan dan tanggungjawab atas pekerjaan pada masingmasing pegawai. Hal ini memicu kesalahpahaman di antara mereka, sementara mereka harus bersinergi untuk menjalankan visi dan misi Kota Pusako. Jika kondisi seperti ini dibiarkan akan menimbulkan dampak negatif pada kinerja staf, dan akan berlanjut pada iklim kerja di lingkungan SKPKD menjadi tidak kondusif dan munculnya perilaku disfungsi staf. Keberadaan struktur organisasi dan uraian pekerjaan yang jelas akan memberikan aktivitas bagi anggota organisasi untuk tidak melakukan tindakan disfungsi (Ludigdo, 2007).

Fenomena yang terjadi di lingkungan SKPKD kota Pusako boleh dikatakan secara umum tidak sejalan dengan tuntutan idealisme dinamika kebutuhan yang sedang terjadi. Struktur organisasi pemerintah memang terpancang pada ketentuan legal formal organisasi dengan berpedoman pada struktur yang hirarkis. Struktur organisasi harus disesuaikan dengan isu kebutuhan dalam peraturan, atau dengan kata lain diperlukan restrukturisasi atau rekayasa ulang terhadap organisasi SKPKD kota Pusako sebagai organisasi birokrasi pelayanan publik sebagai respon organisasi untuk memenuhi tuntutan yang menghendaki pelayanan yang lebih baik dari organisasi bersangkutan. Pengembangan struktur organisasi yang cocok dengan keadaan terkini sangat dibutuhkan sehingga dapat menyempurnakan kinerja SKPKD secara keseluruhan.

Komitmen Terhadap Kompetensi, Kebijakan Sumber Daya Manusia dan Prosedur Perekrutan Sumber Daya Manusia. SKPKD Kota Pusako merupakan organisasi yang sedang bergolak, memiliki sumber daya manusia yang terdiri dari berbagai disiplin ilmu dengan tujuh 
puluh satu orang tenaga tetap dan lima orang tenaga honorer (dokumen pegawai bagian keuangan Kota Pusako tahun 2007). Peranan manajemen SKPKD Kota Pusako sangat berperan penting untuk mengorganisasi dan memanfaatkan sumber daya yang tersedia sedemikian rupa sehingga memperlancar pencapaian tujuan akhir organisasi. Dalam rangka menciptakan aparatur pemerintah yang bersih dan berwibawa, jujur dan bertanggung jawab serta profesional dalam menangani bidang pekerjaan, maka pemerintah telah mengeluarkan satu paket kebijakan yaitu tentang Pendidikan dan pelatihan dalam jabatan bagi PNS yang diatur dalam PP No. 14 tahun 1994. Hal ini dimaksudkan untuk meningkatkan mutu profesionalisme, kesetiaan, dan pengembangan wawasan bagi PNS.

Banyak peraturan yang telah dikeluarkan terkait dengan penempatan pegawai dalam sebuah jabatan, namun masih ditemukan adanya benturan kepentingan yang dihadapi oleh SKPKD Kota Pusako. Pernyataan dari informan Ibu Sarah, yang menjabat sebagai kasi Pembukuan, sedikit mendeskripsikan yang terjadi dalam menempatkan seseorang untuk menjabat suatu posisi dalam struktur organisasi SKPKD Kota Pusako.

"...kuasa BUD kita pada awalnya adalah Bu Wati, tak lama setelah diangkat muncul masalah, ........., lalu muncul protes dari beberapa pegawai karena menganggap bu $\mathrm{Bu}$ Wati belum pantas menjabat sebagai kuasa BUD karena dalam aturannya kuasa BUD adalah pejabat struktural atau pernah menjabat di jabatan struktural. Sedangkan $\mathrm{Bu}$ Wati masih golongan IIIa. Akhirnya ditunjuklah pak Ruta sebagai kuasa BUD"

Bapak Solihin, salah seorang staf anggaran, juga mengatakan bahwa:

"...sudah dari awal saya mengingatkan ke kabag, bahwa yang seharusnya menjabat kuasa BUD adalah pegawai yang pernah atau mempunyai jabatan struktural, tapi beliau kukuh untuk menempatkan Wati sebagai kuasa BUD, nah ketika muncul masalah barulah Wati itu diganti oleh Ruta".

Kondisi yang dijelaskan dua informan sebelumnya menimbulkan masalah, salah satunya berupa kecemburuan antar pegawai yang merasa mempunyai kemampuan dan basis pendidikan yang bagus menjadi terhambat karirnya karena proses rekrutmen yang tidak "fair" ini sehingga dapat mengganggu lingkungan kerja. Pola rekrutmen yang terjadi tidak berpedoman kepada analisis kebutuhan. Belum ada perencanaan kebutuhan pegawai yang matang, kebijakan rekrutmen bersifat inkremental dan parsial. Proses rekrutmen yang kurang terencana ini dapat menghasilkan para pegawai yang kurang memenuhi standar kualifikasi minimal.

Diakui oleh pak Solikin bahwa orang-orang yang menjabat posisi kunci dalam organisasi SKPKD kota Pusako yang lama boleh dikatakan tidak sesuai dengan kebutuhan. Misalnya, posisi Kasubbag Verifikasi yang ditempati oleh Pak Ibrahim yang berlatar belakang pendidikan agama. Sebelum menjadi Kasubbag Verifikasi di SKPKD Kota Pusako Bapak Ibrahim merupakan salah seorang juru penerangan pegawai dinas sosial Provinsi Jambi yang dilikuidasi pada zaman pemerintahan Presiden Abdurahman Wahid. Selanjutnya, posisi Kasubbag perbendaharaan yang ditempati oleh Bapak Ruta yang juga merangkap sebagai kuasa BUD Kota Pusako memiliki latar belakang pendidikan hukum. Sebelum menjabat di Kasubbag Perbendaharaan, Bapak Ruta menjabat sebagai Kasubbag Kepegawaian. Kondisi latar belakang dua pegawai ini mengakibatkan kemampuan adaptasi yang tidak cukup untuk menghadapi terjadi perubahan peraturan yang sedemikan drastis. Para pegawai yang menghadapi masalah pengelolaan keuangan tentu saja membutuhkan saran dan kebijakan dari mereka sebagai pimpinan. Namun kenyataan yang dihadapi pegawai adalah seringkali tidak memperoleh solusi karena pimpinan mereka tidak menguasai masalah pekerjaan yang dihadapi. Pegawaipun diberikan kewenangan untuk membuat kebijakan untuk menyelesaikan permasalahan yang dihadapi. Kondisi ini tentu saja bukan sebuah kondisi yang ideal dalam melaksanakan aktivitas pengendalian karena tidak ada otoritas yang memadai untuk memverifikasi suatu persoalan, misalnya saja terkait dengan dokumen keuangan yang berdasarkan peraturan terbaru.

Penempatan pegawai memerlukan perhatian yang penuh dari pimpinan daerah dan pimpinan SKPKD Kota Pusako. Menurut Penulis, apabila orang yang ditempatkan tidak tepat pada jabatanjabatan yang tersedia akan memberikan pengaruh yang negatif terhadap perkembangan organisasi antara lain: para pegawai akan merasa frustasi dalam bekerja, para pegawai akan bekerja lamban dan hasil kerjanya kurang bermutu, kemungkinan sering terjadi kesalahan-kesalahan dan kekeliruan yang lebih besar karena sesuatu pekerjaan 
dikerjakan oleh bukan ahlinya, para pegawai tidak dapat menggali potensi dirinya untuk organisasi karena pekerjaan tidak sesuai dengan minatnya, dan hasil yang dicapai organisasi tidak sebagaimana mestinya, banyak terjadi penghamburan dan penggunaan material yang siasia.

Hal penting lainnya terkait dengan perencanaan pegawai secara menyeluruh dan terpadu, dan berpedoman pada visi dan misi organisasi adalah tidak tersedianya sistem informasi manajemen yang memadai di bidang kepegawaian. Melalui observasi partisipatif, ditemukan bahwa database kepegawaian yang ada belum mampu memberikan informasi secara valid mengenai sistem kepegawaian, berapa jumlah dan kualifikasi minimal yang dibutuhkan dalam organisasi SKPKD Kota Pusako. Sangat sulit untuk dapat merancang sebuah kebutuhan pegawai dalam jangka panjang dan berkesinambungan jika organisasi tidak memiliki informasi kepegawaian yang valid.

Peranan Kepemimpinan dalam Filosofi Manajemen dan Gaya Operasi. Pengendalian yang efektif dalam suatu organisasi dimulai dan diakhiri dengan filosofi manajemen. Jika manajemen percaya bahwa pengendalian penting, manajemen akan memastikan bahwa kebijakan dan prosedur pengendalian diterapkan secara efektif. Untuk mengkomunikasikan pentingnya pengendalian dilakukan melalui gaya operasi manajemen. Di sini pemimpin memiliki peran penting untuk mengarahkan aktivitas manajemen untuk mencapai sasaran organisasi. Pemimpin menetapkan dan menyampaikan nilai-nilai dan visi organisasi, kemudian mengembangkan strategi dasar untuk meraih tujuan dari visi organisasi tersebut. Pemimpin kemudian mendelegasikan wewenang kepada bawahannya yang mampu untuk mengembangkan dan mengimplementasikan strategi ke dalam organisasi guna meraih visi organisasi. Untuk mengarahkan aktivitas agar mencapai sasaran organisasi diperlukan kemampuan dengan menggunakan kekuasaan (power) untuk mempengaruhi perilaku para anggotanya dengan berbagai cara. Dalam organisasi apapun bentuknya, kepemimpinan merupakan faktor yang turut menentukan tercapainya tujuan organisasi secara lebih efektif dan efisien.

Pemimpin memegang peranan yang strategis dalam sebuah organisasi, termasuk birokrasi publik. Keberhasilan birokrasi publik dalam menjalankan tugas-tugasnya sangat ditentukan kualitas pemimpinnya. Oleh karena itu kedudukan pemimpin sangat mendominasi semua aktivitas yang dilakukan. Organisasi SKPKD Kota Pusako sangat merindukan seorang pemimpin yang dapat mengayomi seluruh pegawainya. Hal ini terungkap dalam pernyataan yang dikemukakan Ibu Eli, seorang staf seksi anggaran:

“...Berbeda dengan kabag sebelum Pak Okta ini, ....Pak Rudin, beliau sangat bijak menghadapi pegawainya. Ketika ada kegiatan, misal seperti bintek sekarang ini, beliau akan mendampingi pegawainya, paling tidak menanyakan kesulitan yang mungkin kami hadapi. Atau saat menyusun anggaran, beliau tanpa sungkan ikut begadang dengan kami. Kalau ada gesekan...., seperti yang terjadi sekarang, Saran dari pegawai Pak Rudin selalu didengar, kalau sarannya untuk hal yang positif pasti dia dengar...Beda sekali dengan Pak Okta yang jadi kabag sekarang. Orangnya arogan, gak mau dengar pendapat orang lain, sok ngatur, padahal belum tentu dia ngerti..."

Sifat arogan dari Bapak Okta juga mendapat perhatian dari Ibu Sarah, salah seorang kasubbag. Dia mengatakan:

“...Ada kejadian yang buat kami kesal dengan kabag. Terlebih Bakri, dia tidak terima dengan perlakuan dari kabag, hal ini disebabkan ketika dia lagi lembur di ruangan verifikasi menyebabkan Bakri tidak bisa ikut apel sore, tapi oleh kabag ditandai cp (cepat pulang) di daftar absen. Pak Okta (kabag) tidak mengkonfirmasi lagi kepada yang lain mengenai alasan Bakri tidak hadir apel. Kemudian Bakri melapor ke kabag dan menanyakan kenapa namanya dicoret sedangkan dia ada di ruangannya untuk menyelesaikan kerjaan kantor. Ehh kabag malah marah-marah dan menantang untuk berkelahi di depan pegawai. Para pegawai kemudian mencoba melerai. Kemudian ada lagi kejadian ketika bang roni tidak datang karena sakit. Bang Roni tidak bisa hadir karena sakitnya mendadak. Kemudian Bang Roni sms ke saya, saya lalu melapor ke kabag. Kabag malah marah, dan menanyakan kenapa Roni tidak langsung sms ke beliau langsung. Aku kan bosnya...kata beliau Saya menjadi tidak enak. Lagi pula kenapa sih dia tidak percaya 
dengan bang roni kalau dia sakit, lagi pula bang roni kasubbag di sini, rasanya sulit baginya untuk bohong..."

Hal yang tak berbeda juga dialami oleh pak Solikin yang menceritakan hal yang menyebabkan ia tidak mau ikut apel, baik apel pagi maupun apel sore dan ketika staf menyarankan untuk merencanakan pekerjaan yang mungkin akan berguna bagi organisasi SKPKD:

“...Percuma Yud, kalau saya kan datang ke kantor setelah ngantar anak berangkat sekolah. Abis ngantar langsung ke kantor, pegawai masih belum banyak yang datang dan meneruskan pekerjaan kemarin. Pas apel kerjaan saya lagi tanggung, saya tidak ikut apel pagi. Hal ini sering. Karenanya ketika di absen saya tidak ada, padahal ada dalam ruangan. Hal ini juga terjadi waktu apel sore, saya ada dalam ruangan. Yudi kan tau kalo kito pulang paling sore. Tidak pernah kita pulang sebelum jam 4 sore. akhirnya tidak diabsen lagi. Sejak itu saya tidak mau lagi tandatangan absen. Terserah mau di isi apa saja. Masa kabag ngurusin absen...masih banyak lagi gawe yang mau di buat...seperti membuat sisdur untuk pedoman kita kerja, dari awal tahun saat menyusun anggaran sudah diingatkan oleh pak Muhammad untuk membuat sisdur, tapi katanya menunggu studi banding dari daerah lain...Kita sudah dihubungi oleh pak Muhammad dan kita siap untuk membuatnya. Tapi karena belum apa-apa sudah dimentahkan ya kita jadi malas, sampai sekarang sisdur ini belum ada, akibatnya pegawai bingung karena tidak ada pedoman kerja...menunggu studi banding..., belum tahu kapan akan dilaksanakan sementara SPPD yang keluar jalan terus, kita tidak tahu harus melakukan apa ketika timbul masalah terkait transaksi yang terjadi...Jadi los terus.."

Masalah mendasar dalam SKPKD kota Pusako terkait dengan belum adanya struktur organisasi yang lengkap, sehingga kesulitan dalam menyusun pembagian otoritas dan wewenang. Permasalahan menjadi semakin kompleks ketika timbul komplain dari pegawai mengenai tugas apa yang harus ia laksanakan, karena tidak adanya keputusan secara resmi mengenai tugas pokok dan fungsi yang harus ia jalankan. Masalah ini menimbulkan lingkungan kerja yang tidak kondusif antar pegawai. Saling tolak untuk melaksanakan tugas pun terjadi. Lambannya antisipasi dari pimpinan organisasi menyebabkan dampak domino terhadap pengendalian akuntansi. Terjadinya pengeluaran keuangan untuk SKPD yang tidak sesuai dengan prosedur pengeluaran merupakan salah satu dampaknya.

Hal ini terjadi ketika SKPD sekretariat DPRD kota Pusako meminta agar SKPKD mengeluarkan biaya perjalanan dinas anggota DPRD. Dokumen yang seharusnya dikeluarkan berdasarkan permintaan SKPD adalah SPP-UP. Namun karena tekanan agar uangnya harus segera diterima oleh SKPD maka oleh SKPKD yang dikeluarkan adalah SPP-LS, karena pagu untuk SPP-UP dibatasi, sementara salah satu syarat jika ia bukan SPP-LS pembayaran gaji dan tunjangan adalah adanya surat perjanjian kerja sama/kontrak kerja antar pengguna anggaran/kuasa anggaran dengan pihak ketiga serta mencantumkan nomor rekening bank pihak ketiga. Hal ini terjadi karena pegawai yang mengajukan SPP belum memperoleh pemahaman mengenai SPP yang harus dikeluarkan dan siapa yang harus mengerjakan untuk membuat dokumen serta siapa yang harus memeriksa dokumen yang diajukan. Selama pengamatan ada tiga instansi yang diperlakukan seperti di atas dengan jumlah rata-rata di atas Rp. 50 juta, karena SPP-UP di batasi hingga 50 juta untuk SKPD kecil dan Rp. 150 juta untuk SKPD besar. Jika hal ini terus terjadi maka pengeluaran belanja yang dikeluarkan oleh SKPKD untuk SKPD telah menyalahi peraturan.

Keterangan di atas sedikit menggambarkan tentang perilaku Pejabat Pengelolaan Keuangan Daerah (PPKD) selaku Bendahara Umum Daerah (BUD) yang merupakan kepala bagian keuangan daerah belum memiliki fungsi pemimpin. Fungsi pemimpin antara lain sebagai pengambil keputusan, memotivasi stafnya, sebagai sumber informasi, menciptakan inspirasi, menciptakan keadilan, menyelesaikan konflik, memberi sugesti pada staf, perencana, integrator, komunikator, memandang ke depan (memiliki visi), pengembangan loyalitas, sebagai seorang ahli, pengawas hubungan antar individu dan kelompok (Djanaid, 1994). Sikap yang ditunjukkan belum mencerminkan sebagai seorang pemimpin efektif yang harus mampu memadukan orientasi pada pekerjaan dan orientasi pada hubungan manusia.

Dari pengamatan Penulis, Orientasi tugas yang tinggi, dengan orientasi hubungan manusia yang rendah dilakukan oleh PPKD akan menciptakan gaya kepemimpinan yang otokratis. Hal ini ditandai dengan penggunaan kewenangan formal dalam menggerakkan bawahannya, 
penggunaan sanksi menjadi pilihan dalam memberikan tindakan kepada bawahan. Dalam pengambilan keputusan peran pemimpin sangat sentral, tidak melibatkan bawahan, bawahan bersifat apatis, dan menerima apapun yang menjadi keputusan pemimpin. Menurut hemat Penulis, peran bawahan dalam pengambilan keputusan tidaklah kecil, karena sumber informasi yang valid berasal dari bawahan sebagai pelaksana di lapangan. Selain itu pemimpin tidak mau menerima saran atau pendapat dari bawahan. Keputusan yang diambil secara sepihak oleh pimpinan kadang-kadang menimbulkan kerancuan dalam pelaksanaan akibat tidak dilibatkannya para bawahan. Keadaan ini membawa implikasi terhadap kinerja, motivasi, dan kepuasan kerja bawahan menjadi rendah.

Penulis memiliki pandangan bahwa seorang pemimpin yang baik adalah pemimpin yang peka dan kritis terhadap kebutuhan dan tuntutan pengikutnya serta mampu juga menganalisa kondisi lingkungan. Pemimpin memiliki inisiatif yang tinggi atau peka dan kritis akan mengetahui kapan ia harus memutuskan untuk melakukan suatu kebijakan, atau kapan ia harus meninggalkannya berkenaan dengan kesinambungan organisasi ke depan. Kemampuan menganalisa kondisi lingkungan memungkinkan pemimpin untuk tidak terjebak dalam kesalahan dalam membuat suatu kebijakan berkaitan dengan tanggung jawabnya. Kualitas kepemimpinan yang dikehendaki tersebut sangat penting agar yang dipimpinnya mau secara ikhlas melaksanakan dan mendukung tugas yang diembannya, dengan begitu optimalisasi pelaksanaan kewajiban dan tanggung jawab organisasi terletak pada seberapa besar produktivitas keberadaan kepemimpinan yang diciptakan dalam pelaksanaan tugas demi tercapainya tujuan organisasi.

Aktivitas Pengendalian Akuntansi Dalam Pemahaman Functionalism Structural Parsons. Strategi analisis struktural fungsionalisme Parsons mensyaratkan bahwa suatu sistem dan tindakan manusia harus menyesuaikan diri dengan lingkungan. Dalam konteks inilah kerangka A-G-IL (Adaptation, Goal Attainment, Integration, Latent Maintenance) digunakan untuk melihat aktivitas pengendalian akuntansi, utamanya faktor-faktor lingkungan pengendalian intern yang merupakan pondasi untuk melaksanakan aktivitas pengendalian akuntansi sektor publik di SKPKD kota Pusako. Untuk menentukan setiap faktor akan dirangkaikan dengan masing-masing kerangka A-
G-I-L dimulai dengan melihat fenomena yang terjadi di SKPKD kota Pusako yang mengalami masa transisi dalam mengelola keuangan daerah, dimana sejak Januari tahun 2007 mulai mengimplementasikan peraturan Menteri dalam negeri no. 13 tahun 2004. Sebelum tahun 2007, dasar acuan yang digunakan untuk mengelola dan mempertanggungjawabkan keuangan daerah adalah keputusan Menteri dalam negeri tahun 2002 dan PP no. 105 tahun 2000.

Empat premis A-G-I-L dapat dirangkaikan dengan faktor-faktor lingkungan pengendalian adalah, adaptation-struktur organisasi, Goal attainment-cara pembagian otoritas dan tanggung jawab, integration-filosofi manajemen dan gaya operasi, latent maintenance-Komitmen terhadap kompetensi, kebijakan sumber daya manusia dan prosedur. Faktor-faktor lingkungan pengendalian intern dimasukkan ke dalam struktur tindakan umum Parsons akan didapat bagan sebagai berikut:

L \begin{tabular}{|c|c|}
\hline $\begin{array}{l}\text { Filosofi dan Gaya } \\
\text { Operasi - } \\
\text { Kepemimpinan }\end{array}$ & $\begin{array}{c}\text { Komitmen ter- } \\
\text { hadap kompe- } \\
\text { tensi, kebijakan } \\
\text { SDM dan }\end{array}$ \\
\hline A & $\begin{array}{c}\text { Cara Pembagian } \\
\text { Tugas dan } \\
\text { Tanggung Jawab } \\
\text { Tsasi }\end{array}$ \\
\hline
\end{tabular}

Gambar 2. Struktur Sistem Tindakan Umum Lingkungan Pengendalian Intern SKPKD kota Pusako

Sciortin (2012) menjelaskan bahwa apa yang disebut Parsons dengan sistem tindakan umum yaitu; 1) adanya kebutuhan untuk beradaptasi dengan lingkungan dan 2) usaha untuk berhubungan dengan anggota-anggota mahluk manusia lainnya. Hal ini mengindikasikan adanya ketergantungan dari masing-masing sub sistem. Masing-masing dari keempat sub sistem itu memenuhi salah satu dari kebutuhan fungsional. Komitmen terhadap kompetensi, kebijakan SDM dan prosedur perekrutan bertanggung jawab terhadap latent pattern maintenance. Sistem komitmen terhadap kompetensi, kebijakan SDM dan prosedur perekrutan harus bersifat melengkapi, memelihara, dan memperbaiki, baik motivasi individual maupun pola-pola kultural yang menciptakan dan menopang motivasi.

Dalam analisis ini, struktur organisasi dilihat 
sebagai institusi yang memiliki tanggung jawab utama terhadap pemenuhan syarat adaptif untuk organisasi sebagai suatu sistem sosial. Sebagai sistem yang adaptif, struktur organisasi merupakan tempat bagi seluruh fasilitas yang primer yang mendasari sistem-sistem lainnya. Struktur organisasi mencakup seperangkat kondisi ke mana tindakan harus disesuaikan dan terdiri dari mekanisme antar hubungan yang utama dengan lingkungan. Pada akhirnya, melalui institusi struktur organisasi inilah sumber daya itu akan digunakan dan dimanfaatkan untuk berbagai tujuan individu dan kolektif.

Pemenuhan proses pencapaian tujuan berpusat pada cara pembagian tugas dan tanggung jawab. Tujuan yang diutamakan disini bukanlah tujuan individu, melainkan tujuan bersama para pegawai dalam organisasi. Tujuan sistem organisasi secara realita berbeda dengan tujuan individu (pegawai) atau pelbagai tujuan kolektivitas lainnya dalam organisasi SKPKD Kota Pusako. Bisa saja tujuan pegawai berhubungan dengan tujuan organisasi terutama perannya sebagai staf di unit kerjanya dalam organisasi. Berdasarkan status-peran masing-masing pegawai diharapkan dapat digunakan sebagai alat untuk merealisasikan tujuan bersama ini.

Integrasi merupakan persyaratan fungsional yang berhubungan dengan interaksi antara para pegawai dalam organisasi SKPKD kota Pusako. Kebutuhan integrasi dalam organisasi ini dapat dipenuhi melalui peran kepemimpinan dalam filosofi dan gaya operasi organisasi. Berfungsinya organisasi dapat berfungsi secara efektif sebagai satu satuan membutuhkan solidaritas antar individu dalam organisasi. Masalah integrasi menunjuk pada kebutuhan untuk menjamin bahwa ikatan emosional yang cukup akan menghasilkan solidaritas dan kerelaan untuk mengembangkan dan mempertahankan kerja sama antar individu. Ikatan-ikatan emosional ini diberikan untuk mencapai tujuan individu dan organisasi. Jika ikatan emosional tidak cukup, solidaritas sosial dan kesediaan untuk kerja sama akan lebih mudah goyah karena hanya didasarkan pada kepentingan diri pribadi semata-mata.

Konsepsi latensi menunjukkan pada berhentinya interaksi. Para anggota dalam sistem sosial apa saja bisa letih dan jenuh serta tunduk pada sistem sosial lainnya di mana mungkin mereka terlibat. Oleh karena itu, semua sistem sosial harus berjaga-jaga bilamana sistem itu sewaktu-waktu berserakan dan para anggotanya tidak lagi berinteraksi sebagai anggota sistem.
Untuk dapat membantu memulihkan dorongan motivasional dan memperbaharui atau memperkuat komitmen terhadap pola-pola budaya organisasi diperlukan mekanisme tertentu yang dikembangkan. Penguatan komitmen dalam SKPKD kota Pusako hal dapat dilihat dalam bentuk: 1) kebijakan SDM melalui sistem bimbingan dan pelatihan, sistem pendidikan untuk meningkatkan kompetensi pegawai dan 2) prosedur perekrutan pegawai yang baik. Kedua bentuk ini akan mengurangi latensi yang terjadi, sehingga calon pegawai baru akan menyumbang fungsi pattern maintenance untuk mempertahankan pola-pola budaya organisasi dan mampu beradaptasi dengan perubahan dengan baik.

Teori Struktural Fungsionalisme Parsons mengungkapkan suatu keyakinan terhadap adanya perubahan dan kelangsungan sistem. Seluruh sub sistem dalam suatu sistem harus saling berinteraksi untuk menghadapi setiap perubahan meskipun dalam prosesnya terdapat kemungkinan adanya konflik. Setiap faktor lingkungan pengendalian internal dalam organisasi SKPKD kota Pusako melakukan integrasi dalam suatu sistem terpadu, sehingga masing-masing faktor tersebut harus menyesuaikan diri terhadap segala perubahan untuk mendukung terlaksananya aktivitas pengendalian internal SKPKD Kota Pusako.

Perubahan sistem membuat organisasi SKPKD mulai berbenah untuk mengakomodir seluruh aspek perubahan pengelolaan dan pertanggungjawaban keuangan daerah yang terjadi. Perubahan yang terjadi sangat mendasar bahkan dapat dikatakan sangat drastis karena menyangkut perubahan paradigma sehingga membutuhkan waktu untuk beradaptasi terhadap perubahan peraturan tersebut. Salah satu konsekuensi dari perubahan tersebut adalah timbulnya suatu ketegangan.

Ketegangan dapat dilihat sebagai suatu ketidaksesuaian antara keadaan suatu sistem sekarang ini dan suatu keadaan yang diinginkan, atau sebagai kurangnya suatu pemuasan yang menyenangkan, atau keseimbangan yang semakin berkurang. Ketegangan ini merangsang penyesuaian dari suatu tujuan tertentu serta menggiatkan semangat dorong yang diarahkan ke pencapaian tujuan. Pencapaian tujuan itu memberikan kepuasan yang diharapkan dapat bahkan mengurangi atau mengatasi ketegangan. Namun, sebelum suatu tujuan dapat tercapai, harus ada suatu tahap penyesuaian terhadap keadaan genting dari situasi di mana sumber daya dan sarana harus dikerahkan dan disiapkan untuk 
mencapai tujuan.

Selama tahap latensi, pemuasan harus ditunda. Pemuasan dalam hal ini dapat berupa pemenuhan keinginan individu dalam memperoleh kesejahteraan. Harus ada tingkat solidaritas minimal diantara para anggota organisasi sehingga sistem itu dapat bergerak sebagai satu satuan menuju tercapainya tujuan itu. Tak dapat dipungkiri bahwa tuntutan pelaksanaan tugas yang disiplin yang dikenakan pada para anggota organisasi pada saat bergerak maju menuju tujuan sistem akan sering kali cukup merusak solidaritas emosional. Dapat dikatakan bahwa tahap pencapaian tujuan secara khas diikuti oleh suatu tekanan pada integrasi di mana solidaritas keseluruhan diperkuat, terlepas dari usaha apa saja untuk tercapainya tugas instrumental. Pada gilirannya, tahap ini diikuti oleh tahap mempertahankan pola tanpa interaksi atau bersifat laten (latent pattern maintenance).

Realitas, Sistem pengendalian internal belum menjadi penjaga aset daerah Kota Pusako. Aktivitas pengendalian internal, terdeskripsikan sebagai "bangunan" yang berdiri di atas "pondasi" lingkungan pengendalian intern. "Pondasi" ini belum kokoh untuk mendirikan sebuah "bangunan" yang kokoh dan megah. Pengendalian intern di lingkungan pemerintah daerah diatur dalam Permendagri No. 13 Tahun 2006 pasal 313. Melalui peraturan ini SKPKD yang diberi kekuasaan oleh negara untuk mengambil kebijakan-kebijakan berkaitan dengan kinerja fiskal dan anggaran. Kebijakan ini untuk memastikan keefektifan dan keefisienan dalam mengelola aset. Dapat dikatakan bahwa SKPKD belum menjalankan tugas dan fungsinya secara optimal. Kinerja dan pertanggungjawaban anggaran memang telah dikontrol untuk meminimalkan dan mengantisipasi timbulnya pemerintahan yang menyimpang seperti munculnya moral hazard. Moral hazard dapat berupa kebohongan publik yang dilakukan oleh eksekutif kepada masyarakat luas, dilakukannya korupsi, kolusi dan nepotisme oleh pejabat dan atau anggota DPRD. SKPKD masih memerlukan mekanisme sistem akuntabilitas publik yang baik guna mempertanggungjawabkan penggunaan dana rakyat.

\section{SIMPULAN}

Praktik pengendalian internal secara utuh memang sulit ditemukan dalam organisasi SKPKD yang dijelaskan. Hasil eksplorasi atas realitas pengendalian internal SKPKD Kota Pusako menunjukkan adanya faktor lain yang mendasari berjalannya suatu aktivitas. Ibarat sebuah bangunan, aktivitas pengendalian membutuhkan suatu pondasi yang kuat agar dapat berdiri kokoh sehingga mampu melindungi sesuatu yang akan mendiami bangunan tersebut dari segala ancaman yang merugikan. Lingkungan pengendalian merupakan pondasi untuk melaksanakan pengendalian yang dimaksud.

Teori struktural fungsionalisme Parsons mengungkapkan bahwa semua faktor lingkungan pengendalian intern tidak dapat berdiri sendiri, namun saling bergantung dan berkaitan satu dengan yang lain dalam menghadapi setiap perubahan. Sebuah sistem tidak akan akan berjalan dengan semestinya jika salah satu faktor di dalamnya tidak mampu beradaptasi terhadap perubahan yang terjadi. Dalam kasus ini, faktor lingkungan pengendalian seperti struktur organisasi, komitmen terhadap kompetensi, dan peranan kepemimpinan belum menjadi "pondasi" yang kokoh sehingga "bangunan" aktivitas pengendalian internal belum berdiri tegak. Seluruh sub sistem dalam suatu sistem harus saling berinteraksi meskipun dalam prosesnya terdapat kemungkinan adanya konflik. Struktur organisasi, cara pembagian tugas dan tanggung jawab, peran kepemimpinan dalam filosofi dan gaya operasi dan komitmen terhadap kompetensi, kebijakan SDM serta prosedur perekrutan pegawai dalam organisasi SKPKD kota Pusako merupakan suatu integrasi dalam suatu sistem terpadu, masingmasing sub-sistem tersebut harus menyesuaikan diri terhadap segala perubahan untuk mendukung terlaksananya aktivitas pengendalian akuntansi sektor publik kota Pusako.

\section{REFERENCES}

Albrecht, K., (1985), Pengembangan Organisasi: Pendekatan Sistem yang Menyeluruh untuk Mencapai Perubahan Positif dalam Setiap Organisasi, Bandung: Angkasa.

Bastian, I., (2010), Sistem Akuntansi Sektor Publik Edisi 3. Jakarta: Erlangga.

Bodnar, G. H., dan Hopwood, W. S., (2007), Sistem Informasi Akuntansi (Kesembilan ed.). Yogyakarta: Penerbit Andi.

Boynton, W., Johnson, R., dan Kelly, W., (2003), Modern Auditing Buku 1: PA Rajoe, G. G., \& IS Budi (terj.). Jakarta: Erlangga.

Badan Pemeriksa Keuangan, (2014) Ikhtisar Hasil Pemeriksaan Semester I Tahun 2014, Jakarta: BPK RI 
Bungin, B., (2011), Metodologi Penelitian Kualitatif: Komunikasi, Ekonomi, Kebijakan Publik, dan Ilmu Sosial Lainnya. Jakarta: Prenada Media Group.

Covaleski, M. A., dan Dirsmith, M. W., (1988), An Institutional Perspective on The Rise, Social Transformation, and Fall of A University Budget Category, Administrative Science Quarterly, Vol 33 No 4, page 562-587.

Djamhuri, A., (2009), A Case Study of Governmental Accounting and Budgeting Reform at Local Authority in Indonesia: An Institusionalist Perspective, (Doctor Philosophy), University Sains Malaysia, Malaysia.

Djanaid, D., (1994), Kepemimpinan: Teori dan Praktik, Malang: Indonesia Multi Management.

Fatchan, A., (2013), Metode Penelitian Kualitatif: 10 Langkah Penelitian Kualitatif Pendekatan Konstruksi dan Fenomenologi. Malang: Penerbit Universitas Negeri Malang.

Gibson, J. L., Ivancevich, J. M., dan James, H., (1997), Organisasi (N. Adrian, Trans.), Jakarta: Bina Rupa Aksara.

Gill, M. J., (2014), The Possibilities of Phenomenology for Organizational Research, Organizational Research Methods, Vol 17 No 2, page 118-137.

Harun, H., dan Kamase, H.P., (2012), Accounting Change and Institutional Capacity: The Case of a Provincial Government in Indonesia, Australasian Accounting Business $\mathcal{E}$ Finance Journal, Vol 6 No 2, page 35-49.

Independen, J. (2007). Berkas Kasus Disporada Segera Dilimpahkan ke PN. Harian Jambi Independen.

Jones, M. J., (2008), Internal Control, Accountability and Corporate Governance. Accounting, Auditing \& Accountability Journal, Vol 21 No 7, page 1052-1075.

Krismiaji. (2015), Sistem Informasi Akuntansi (Edisi 4 ed.), Yogyakarta: UPP AMP YKPN.

Kurniawan. 2006. Peta Korupsi di Daerah. Jakarta: YAPPIKA.

Kuswarno, E., (2009), Metodologi Penelitian Komunikasi: Fenomenologi; Konsepsi, Pedoman, dan Contoh Penelitiannya. Bandung: Widya Padjajaran.

Ludigdo, U., (2007), Paradoks Etika Akuntan,Yogyakarta: Pustaka Pelajar.

Martani, D., dan Zaelani, F., (2011) Pengaruh Ukuran, Pertumbuhan, dan Kompleksitas terhadap Pengendalian Intern Pemerintah Daerah: Studi Kasus di Indonesia, Artikel dipresentasikan dalam Simposium Nasional Akuntansi XIV, Aceh.

Merdeka, S., (2007), Banyak Uang Negara di Rekening Pejabat, Siara Merdeka.

Miles, M. B., Huberman, A. M. dan Saldana, J., (2014), Qualitative Data Analysis: A Methods Sourcebook (Third ed.): SAGE Publications.

Moleong, J. L., (2007) Metodologi Penelitian Kualitatif. Bandung: Penerbit Remaja Rosda Karya.

Moustakas, C., (1994), Phenomenological Research Methods, CA.

Norhayati, M. A., dan Siti-Nabiha, A. K., (2009), A case study of the performance management system in a Malaysian government linked company, Journal of Accounting $\mathcal{E}$ Organizational Change, Vol 5 No 2, page 243276.

Menteri Dalam Negeri, (2006), Peraturan Menteri DAlam Negeri Nomor 13 Tahun 2006.

Menteri Dalam Negeri, (2007), Surat Edaran Menteri Dalam Negeri No. SE-900/743/BAKD Tahun 2007 Tentang Modul Akuntansi Keuangan Pemerintah Daerah.

Menteri Keuangan Republik Indonesia, (2012), Peraturan Menteri Keuangan Republik Indonesia Nomor 123/ PMK.01/2012.

Perdue, W. D., (1986), Sociological Theory: Explanation, Paradigm, and Ideology. Palo Alto, CA: Mayfield Publishing Company.

Poloma, M. M., (2004), Sosiologi Kontemporer, Jakarta: PT. RajaGrafindo.

Ritzer, G., dan Goodman, D. J., (2012), Teori Sosiolog; Dari Teori Sosiologi Klasik Sampai Perkembangan Mutakhir Teori Sosial Posmodern. Bantul: Kreasi Wacana Offset.

Robert, A., (2006), Quotes from Parsons, Concepts for Sociology: A Middlesex University Resource.

Sciortin, G., (2012), Fungsionalisme dan Teori Sistem-Sistem Sosial. In B. S. Turner (Ed.), Teori Sosial: Dari Klasik Sampai Postmodern. Yogyakarta: Pustaka Pelajar.

Shapiro, B., dan Matson, D., (2008), Strategies of resistance to internal control regulation. Accounting, Organizations and Society, Vol 33 No 2, page 199-228.

Suddaby, R., (2010) Challenges For Institutional Theory. Journal of Management Inquiry, Vol 19 No 1, page 14-20.

Sutiyono, A., dan Sulistiyani, A. T., (2004), Sumber Daya Manusia (SDM) Aparatur Pemerintah dalam Birokrasi Publik di Indonesia. In A. T. Sulistiyani (Ed.), Memahami Good Governance: Dalam Perspektif Sumber Daya 
Manusia (pp. 1-45). Yogyakarta: Penerbit Gaya Media.

Sutiyono, A., Sulistiyani, A. T. dan Sartono, (2004), Sumber Daya Manusia (SDM) Aparatur Pemerintah dalam Birokrasi Publik di Indonesia. In A. T. Sulistiyani (Ed.), Memahami Good Governance: Dalam Perspektif Sumber Daya Manusia, Yogyakarta: Penerbit Gaya Media.

Ter Bogt, H. J., (2008), Management Accounting Change and New Public Management in Local Government: A Reassessment of Ambitions and Results - An Institutionalist Approach to Accounting Change in The Dutch Public Sector, Financial Accountability $\mathcal{E}$ Management, Vol 24 No 3,page 209-241. doi:10.1111/j.1468-0408.2008.00451.x

Triyuwono, I., dan Roekhuddin, (2000), Konsistensi Praktik Sistem Pengendalian Intern dan Akuntabilitas pada Lazis (Studi Kasus di Lazis X Jakarta). Jurnal Riset Akuntansi Indonesia, Vol 3 No 2, page 151-167.

Turner, J. H., (1998), The Structure of Sociological Theory. 6th edition. Cincinnati, $\mathrm{OH}$ : Wadsworth.

Widyaningsih, A., Triantoro, A. dan Wiyantoro, L. S., (2011), Hubungan Efektifitas Sistem Akuntansi Keuangan Daerah dan Pengendalian Intern dengan Kualitas Akuntabilitas Keuangan: Kualitas Informasi Laporan Keuangan sebagai Variabel Intervening (Penelitian pad Laporan Realisasi Anggaran di Pemda Kabupaten/Kota Wilayah Jawa Barat), Artikel dipresentasikan dalam Seminar Nasional Akuntansi XIV, Aceh.

Winidyaningrum, C. dan Rahmawati, (2010), Pengaruh Sumber Daya Manusia dan Pemanfaatan Teknologi terhadap Keterandalan dan Ketepatwaktuan Pelaporan Keuangan Pemerintah Daerah dengan Variabel Intervening Pengendalian Intern Akuntansi, Artikel dipresentasikan dalam Seminar Nasional Akuntansi XIV, Aceh. 